\title{
Subchronic Toxicity of Ethanol Extract of Syzygium polyanthum (Wight) Walp. Leaves on Wistar Rat
}

\author{
Sri Adi Sumiwi ${ }^{1}{ }^{*}$, Ade Zuhrotun ${ }^{1}$, Rini Hendriani ${ }^{1}$, Mochamad Rizal $^{1}$, Jutti Levita ${ }^{1}$, \\ Sandra Megantara ${ }^{2}$ \\ ${ }^{1}$ Department of Pharmacology and Clinical Pharmacy, Faculty of Pharmacy, Universitas Padjadjaran, J1. Raya Bandung-Sumedang Km 21, \\ Jatinangor 45363, Indonesia \\ ${ }^{2}$ Department of Pharmaceutical Analysis and Medicinal Chemistry, Faculty of Pharmacy, Universitas Padjadjaran, Jl. Raya Bandung-Sumedang Km 21, \\ Jatinangor 45363, Indonesia \\ *Corresponding author. E-mail: sri.adi@unpad.ac.id
}

Received date: Apr 23, 2018; Revised date: Aug 2, 2018; Accepted date: Aug 8, 2018

\section{Abstract}

ACKGROUND: Previous works indicated various pharmacology activities of bay plant (Syzygium polyanthum (Wight) Walp.), however only few studies investigated its toxicity. This work was aimed to study the subchronic toxicity of ethanol extract of this plant.

METHODS: White Wistar rats were divided into 4 groups and were treated with $2 \%$ of Arabic gum (PGA) suspension, $1000 \mathrm{mg} / \mathrm{kg}$ of body weight (BW), $400 \mathrm{mg} / \mathrm{kg}$ of BW and $100 \mathrm{mg} / \mathrm{kg}$ of BW, respectively. The animals were observed on their body weight, hematology, clinical biochemistry parameters, organ index and histopathology.

RESULTS: Flavonoids, tannins, polyphenols, saponins, quinones, monoterpenes and sesquiterpenes were detected in dried leaves and ethanol extract of bay plant. An increase of body weight in male and female groups treated with dose 100 and $400 \mathrm{mg} / \mathrm{kg}$ BW compared to controls, was observed. Moreover, there was an increase of white blood cell (WBC) in male and female groups treated with $S$. polyanthum extracts compared to controls, whereas a decrease of red blood cell (RBC) was observed in male groups treated with $S$. polyanthum extracts in dose-dependent manner compared to control. No significant changes of RBC were seen in female groups, haemoglobin values were not altered by extract treatment. Photomicrographs of liver, kidney, lungs, heart and spleen histopathology of male and female S. polyanthum extract-treated groups showed no significant alteration compared to controls.

CONCLUSION: Our study revealed that $S$. polyanthum extracts does not show toxicity on the body weight, hematology, creatinine and serum glutamic pyruvic transaminase (SGPT), but fatty liver and necrosis are observed in female rats. This result can be beneficial for plant-based drug discovery, particularly this study provides information about the safety of S. polyanthum to be further developed as candidate of phytopharmaceutics.

KEYWORDS: bay plants, salam leaves, hepatotoxicity, necrosis, SGOT, SGPT

Indones Biomed J. 2019; 11(1): 30-5

\section{Introduction}

Bay plant (Syzygium polyanthum (Wight) Walp.) has been widely used in Indonesia as food flavour and herbal medicines. Its synonims are Eugenia polyantha Wight and Eugenia lucidula miq.(1) This plant contains tannins, flavonoids and essential oils (0.05\%), which includes citric acid and eugenol (2), while GC-MS analysis of bay leaf essential oils in commercial samples indicated the presence of mono- and sesqui-terpenes, polyphenols and phenolicglucosides (3). Flavonoid contained in E. polyantha Wight had revealed antiinflammatory activity which mechanism was by inhibiting prostaglandine synthesis and stimulating proline hydroxylation.(4) Other pharmacological activities of $S$. polyanthum are antioxidant, antihyperglycemic, 
antihyperlipidemia, antidiarrhea, antihyperuricemia and antimicrobial.(5-12) The antidiarrheal activity was predicted due to the tannins contained in the leaves which had been proven could suppress the peristaltic motion of the gut.(5)

\section{Methods}

\section{Plant Extraction}

The leaves of bay tree were obtained from Subang, West Java, Indonesia, and was taxonomically identified at Laboratory of Plant Taxonomy, Department of Biology, Faculty of Mathematics and Natural Sciences, Universitas Padjadjaran, West Java, Indonesia (specimen No. 411/ HB04/2016). The $S$. polyanthum leaves were separated from the twigs, washed under tap water to remove dirt, dried in a glass-house for 3 days, and pulverized. The powder was then macerated in ethanol $70 \%$ for $3 \times 24$ hours. At the $4^{\text {th }}$ day the macerates were collected and concentrated using Buchi R210/215 rotary evaporator (BÜCHI Labortechnik, Flawil, Switzerland) until a viscous extract of $11.946 \mathrm{~g}$ per $100 \mathrm{~g}$ was obtained.

\section{Phytochemical Screening}

The phytochemical screening was conducted to detect the presence of polyphenols, tannins, alkaloids, quinones, saponins, flavonoids, monoterpenoids, steroids, triterpenoids and sesquiterpenoids as described by Fansworth.(13) The formation of precipitate and/or the change of color intensity after the addition of certain reagents, were observed.

\section{Experimental Animals}

Forty healthy male and female Wistar rats aged 18-20 weeks (200-250 g of body weight (BW)), were purchased from Pusat Rekayasa Industri, Bandung Institute of Technology, Indonesia. Before starting this study, the protocol was approved by Universitas Padjadjaran Health Research Ethics Committee (No. 899/UN6.C1.3.2/KEPK/PN/2016). The rats were acclimatized for 7 days, housed in cages (ten animals per cage: five males and five females, based on Federer calculation), and maintained under standard laboratory conditions with dark and light cycles (12/12 hours) according to the ethical standards. Standard feed and drink were given ad libitum. No vitamins were added in their feed.

\section{Subchronic Toxicity Study}

Forty white Wistar rats of both sexes aged 18-20 weeks (200-250 g of BW) were divided into 4 groups and were treated with $2 \%$ of Arabic gum (PGA) suspension (I), $1000 \mathrm{mg} / \mathrm{kg}$ of BW (II), $400 \mathrm{mg} / \mathrm{kg}$ of BW (III) and $100 \mathrm{mg} / \mathrm{kg}$ of BW (IV), respectively for 90 days as required by subchronic oral toxicity testing (repeated dose 90day oral toxicity testing).(14) The dosing time was set approximately at $11 \mathrm{a} . \mathrm{m}$. to minimize biological variation of the animals.

\section{Body Weight Observation}

The body weight of the animals per cage was measured daily from day- 0 (before treatment) to day- 90 by using OHAUSS animal balance.

\section{Haematological and Biochemical Analysis}

Haematological and biochemical analysis were performed at day-91. The rats were anaesthetized and terminal blood samples were withdrawn through cardiac puncture and collected in ethylenediaminetetraacetic acid (EDTA)tubes.(14) The haematological parameters measured were haemoglobin concentration using Sahli method (15), white blood cells (WBC), and red blood cells (RBC). The biochemical parameters measured were serum glutamic oxaloacetic transaminase (SGOT), serum glutamic pyruvic transaminase (SGPT) (for liver function), and creatinine (for kidney function).

\section{Histopathology and Organ Index Observation}

This step was performed in the Laboratory of Animal Microtechniques, Department of Biology, Faculty of Mathematics and Natural Sciences, Universitas Padjadjaran. The animals were sacrificed and the organs (heart, liver, kidney, lung and spleen) were excised and weighed. The organ indexes were calculated as organ/body weight $x$ $100 \%$.(16) The organs were preserved in Bouin solution for 48 hours to be used for further examination. The sections were stained using haematoxylin and eosin.

\section{Statistical Analysis}

Data were expressed as mean value. Significant differences were determined by student t-test using $p<0.05$.

\section{Results}

\section{Phytochemical Screening}

Phytochemical screening revealed that dried leaves and ethanol extract of $S$. polyanthum contained flavonoids, tannins, polyphenols, saponins, quinones, monoterpenes and sesquiterpenes. 


\section{Body Weight Observation}

The body weight of the animals per cage was measured daily from day- 0 (before treatment) to day- 90 . The extent of observations made in subchronic studies may vary with the known properties of the compound and the purpose of the test. In general, they include daily inspection for physical appearance (posture, gait, thriftiness), behavior (activity), weekly records of body weight and food consumption, and character of excreta.(17)

During 90 days study, no death or changes in behavior and physical appearance, were observed in all groups of animals. There was an increase of body weight although not significant, in male and female groups treated with $S$. polyanthum extracts dose 100 and $400 \mathrm{mg} / \mathrm{kg} \mathrm{BW}$ compared to controls. A decrease of body weight was observed in male group treated with $1000 \mathrm{mg} / \mathrm{kg}$ BW extract. Food and water consumption of all animals were found to be normal.

\section{Haematological and Biochemical Analysis}

The haematological and biochemical analysis were provided in Table 1.

\section{Organ Index Observation}

On the 91st day, organ to body weight ratios of lungs, heart, liver and kidney in males were slightly decreased at dose $1000 \mathrm{mg} / \mathrm{kg}$ BW compared to control although not significant $(p<0.05)$, whereas that of spleen was not significantly increased. The liver indexes of female group at dose $1000 \mathrm{mg} / \mathrm{kg} \mathrm{BW}$ and $400 \mathrm{mg} / \mathrm{kg} \mathrm{BW}$ were significantly higher compared to control.

\section{Histopathology}

At the end of treatment, vital organs (including liver, kidney, heart, lungs and spleen) were subjected to histopathological examination. The microscopic observation showed no remarkable pathological changes for all organs in S. polyanthum extract-treated groups, males and females, compared to controls (Figure 1-5).

\section{Discussion}

The history of toxicity studies begins with Paracelsus (14931541), a physician, alchemist and astrologer, who suggested that specific chemicals were responsible for the observed toxicity of plants and animals. He demonstrated the harmless and beneficial effects of toxins and proved dose-response relationships for the effects of drugs. Paracelsus is very wellknown with his quote: All substances are poisons; there is none which is not a poison. The right dose differentiates a poison and a remedy.(18) The US National Cancer Institute (NCI) developed a test to identify carcinogenic chemicals through the daily dosing of rats and mice for 2 years.

At present, all the regulatory agencies concentrated on determining the toxicity profiles of all pharmaceutical substances available for regular patient use and made mandatory the submission of toxicity profiles of

Table 1. Haematological and biochemical analysis.

\begin{tabular}{|c|c|c|c|c|c|c|}
\hline Animal Group & $\begin{array}{c}\text { WBC } \\
\left(10^{3} / \mathrm{mm}^{3}\right)\end{array}$ & $\begin{array}{c}\text { RBC } \\
\left(10^{6} / \mathrm{mm}^{3}\right)\end{array}$ & $\begin{array}{c}\text { Haemoglobin } \\
\text { (g/dL) }\end{array}$ & $\begin{array}{l}\text { SGOT } \\
\text { (IU/L) }\end{array}$ & $\begin{array}{l}\text { SGPT } \\
\text { (IU/L) }\end{array}$ & $\begin{array}{c}\text { Creatinine } \\
\text { (mg/dL) }\end{array}$ \\
\hline Male control & 6.35 & 4.04 & 12.14 & 130 & 76 & 0.89 \\
\hline Male $1000 \mathrm{mg} / \mathrm{kg} \mathrm{BW}$ & $\begin{array}{c}10.56 \\
p=0.06\end{array}$ & $\begin{array}{c}3.83 \\
p=0.57\end{array}$ & $\begin{array}{c}12.25 \\
p=0.92\end{array}$ & $\begin{array}{c}102 \\
p=0.01\end{array}$ & $\begin{array}{c}66.75 \\
p=0.44\end{array}$ & $\begin{array}{c}0.82 \\
p=0.20\end{array}$ \\
\hline Male $400 \mathrm{mg} / \mathrm{kg}$ BW & $\begin{array}{c}8.26 \\
p=0.40\end{array}$ & $\begin{array}{c}3.85 \\
p=0.60\end{array}$ & $\begin{array}{c}11.55 \\
p=0.61\end{array}$ & $\begin{array}{c}162.25 \\
p=0.53\end{array}$ & $\begin{array}{c}80.25 \\
p=0.72\end{array}$ & $\begin{array}{c}0.8 \\
p=0.10\end{array}$ \\
\hline Male $100 \mathrm{mg} / \mathrm{kg} \mathrm{BW}$ & $\begin{array}{c}8.58 \\
p=0.42\end{array}$ & $\begin{array}{c}4.18 \\
p=0.79\end{array}$ & $\begin{array}{c}12.59 \\
p=0.76\end{array}$ & $\begin{array}{c}103 \\
p=02\end{array}$ & $\begin{array}{c}54.5 \\
p=0.13\end{array}$ & $\begin{array}{c}0.67 \\
p=0.03\end{array}$ \\
\hline Female control & 8.28 & 4.2 & 12.61 & 99.25 & 53.75 & 0.72 \\
\hline Female $1000 \mathrm{mg} / \mathrm{kg} \mathrm{BW}$ & $\begin{array}{c}9.03 \\
p=0.54\end{array}$ & $\begin{array}{c}4.49 \\
p=0.36\end{array}$ & $\begin{array}{c}13.51 \\
p=0.36\end{array}$ & $\begin{array}{c}129 \\
p=0.25\end{array}$ & $\begin{array}{c}69.25 \\
p=0.27\end{array}$ & $\begin{array}{c}0.77 \\
p=0.49\end{array}$ \\
\hline Female $400 \mathrm{mg} / \mathrm{kg} \mathrm{BW}$ & $\begin{array}{c}7.87 \\
p=0.90\end{array}$ & $\begin{array}{c}3.77 \\
p=0.42\end{array}$ & $\begin{array}{c}11.31 \\
p=0.43\end{array}$ & $\begin{array}{c}114 \\
p=0.39\end{array}$ & $\begin{array}{c}63 \\
p=0.55\end{array}$ & $\begin{array}{c}0.74 \\
p=0.80\end{array}$ \\
\hline Female $100 \mathrm{mg} / \mathrm{kg} \mathrm{BW}$ & $\begin{array}{c}8.08 \\
p=0.88\end{array}$ & $\begin{array}{c}4.07 \\
p=0.70\end{array}$ & $\begin{array}{c}12.21 \\
p=0.70\end{array}$ & $\begin{array}{c}92.25 \\
p=0.64\end{array}$ & $\begin{array}{c}47.5 \\
p=0.50\end{array}$ & $\begin{array}{c}0.75 \\
p=0.70\end{array}$ \\
\hline
\end{tabular}




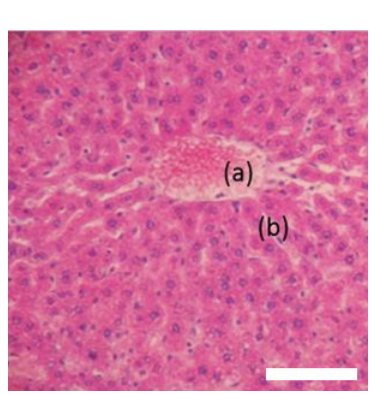

Control

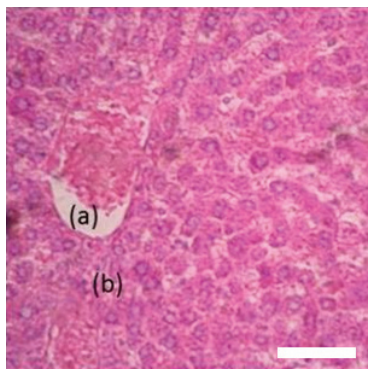

Control

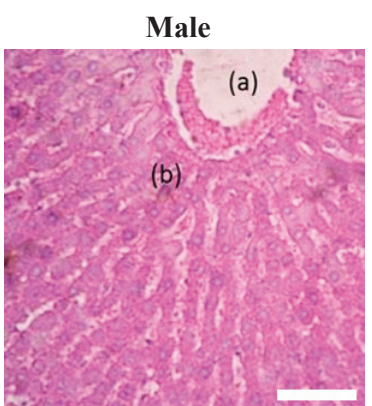

Dose $400 \mathrm{mg} / \mathrm{kg} \mathrm{BW}$

Female

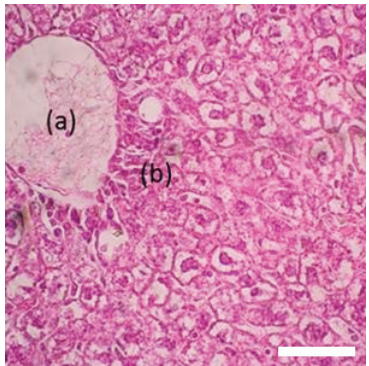

Dose $400 \mathrm{mg} / \mathrm{kg} \mathrm{BW}$

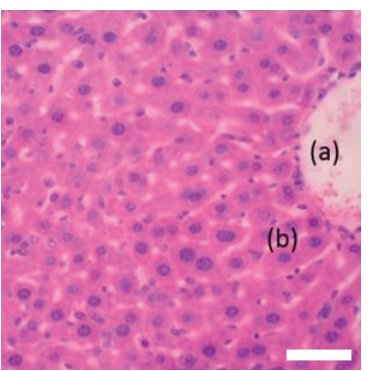

Dose $1000 \mathrm{mg} / \mathrm{kg} \mathrm{BW}$

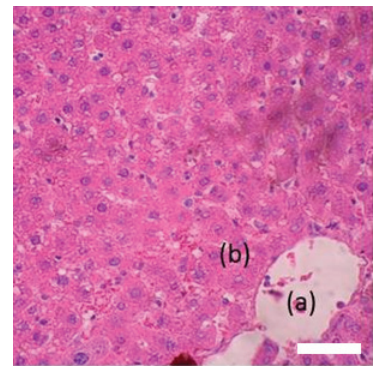

Dose $1000 \mathrm{mg} / \mathrm{kg} \mathrm{BW}$

Figure 1. Photomicrographs of liver histopathology of male and female controls and S. polyanthum extract-treated groups. (a): central vein; (b): sinusoids. No significant alteration was detected. White bar: $100 \mu \mathrm{m}$.

investigational new drugs (IND). Rodents and nonrodents are used to study the subchronic toxicity of a substance. The test substance is administered orally for 90 days, and weekly body weight variations, monthly biochemical and cardiovascular parameters changes, and behavioral changes are observed.

At the end of the study, the experimental animals are sacrificed. Gross pathological changes are observed, and

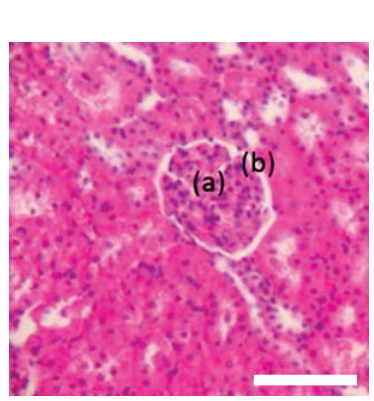

Control

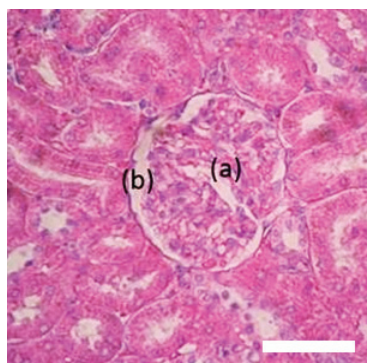

Control

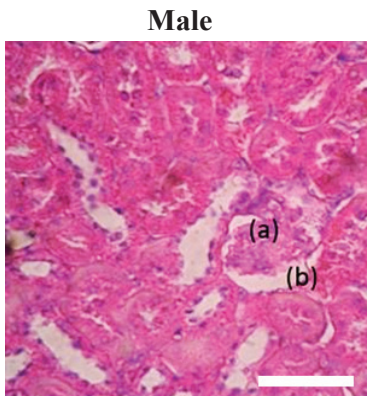

Dose 400 mg/kg BW

Female

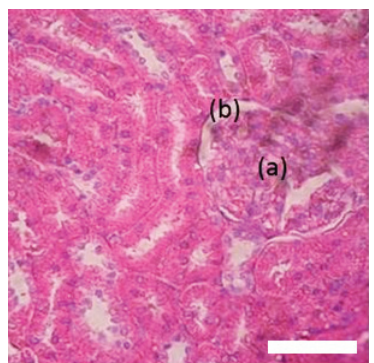

Dose $400 \mathrm{mg} / \mathrm{kg} \mathrm{BW}$

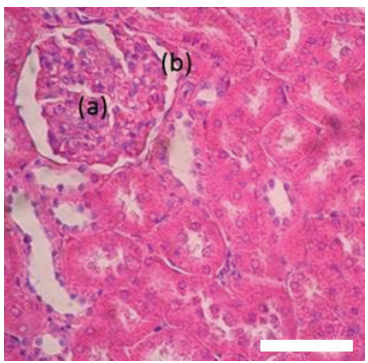

Dose 1000 mg/kg BW

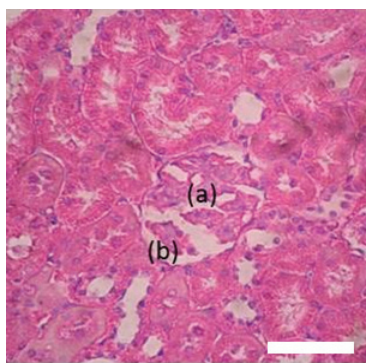

Dose $1000 \mathrm{mg} / \mathrm{kg} \mathrm{BW}$

Figure 2. Photomicrographs of kidney histopathology of male and female controls and $S$. polyanthum extract-treated groups. (a): glomerulus; (b): Bowman capsule. No significant alteration was detected. White bar: $100 \mu \mathrm{m}$. 


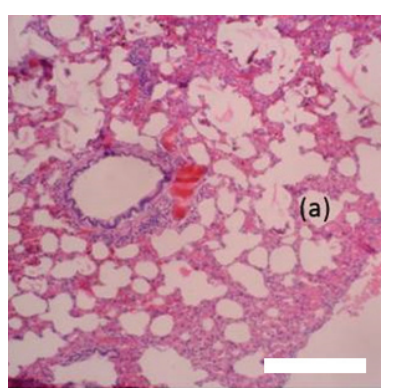

Control

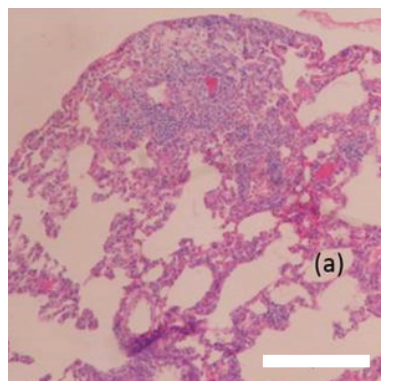

Control

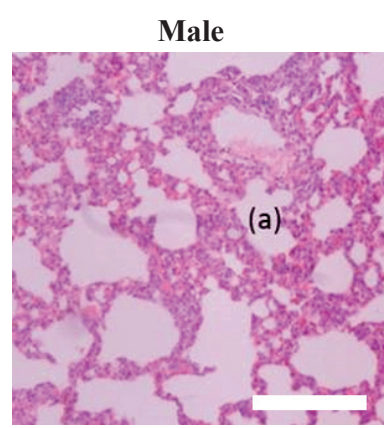

Dose $400 \mathrm{mg} / \mathrm{kg} \mathrm{BW}$

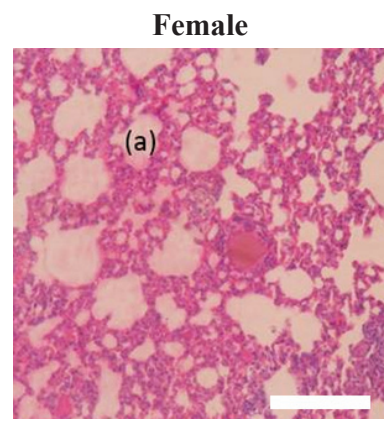

Dose $400 \mathrm{mg} / \mathrm{kg} \mathrm{BW}$

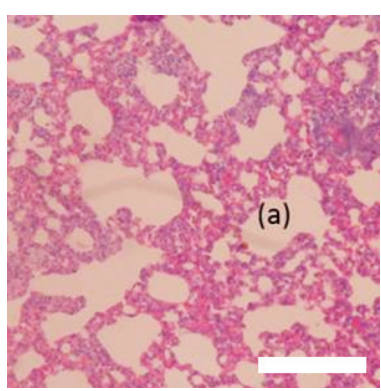

Dose $1000 \mathrm{mg} / \mathrm{kg} \mathrm{BW}$

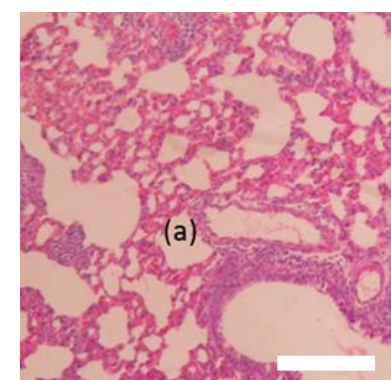

Dose 1000 mg/kg BW

Figure 3. Photomicrographs of lungs histopathology of male and female controls and $S$. polyanthum extract-treated groups. (a): alveolus. No significant alteration was detected. White bar: $100 \mu \mathrm{m}$.

all the tissues are subjected to histopathological analyses. There should be little individual variation between the animals, and the allowed weight variation range is $\pm 20 \%$.(14)
Our subchronic toxicity study of oral administration of S. polyanthum extract up to $1000 \mathrm{mg} / \mathrm{kg} \mathrm{BW}$ for 90 days generally indicates no toxicity in rats, however further clinical studies are needed to confirm its safety.

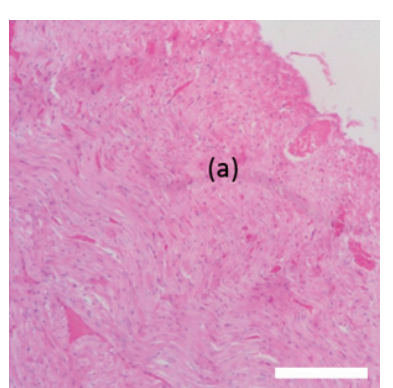

Control

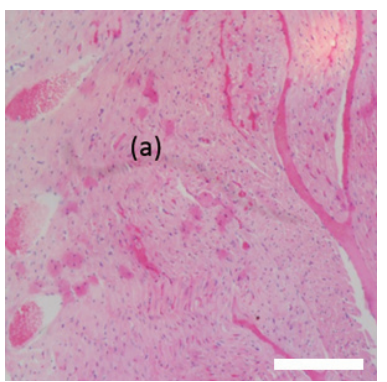

Control

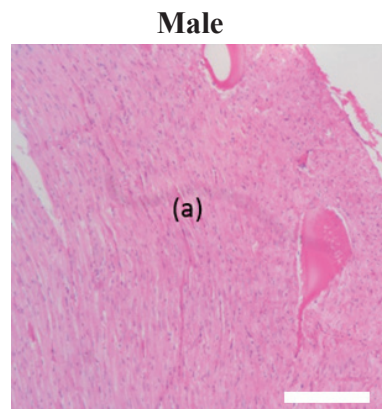

Dose $400 \mathrm{mg} / \mathrm{kg} \mathrm{BW}$

Female

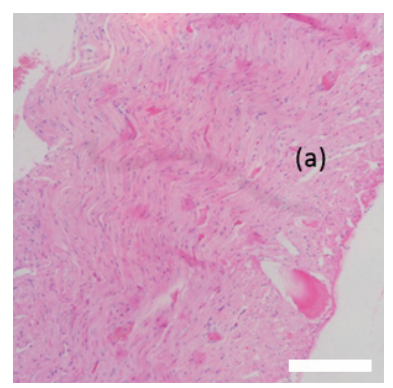

Dose $400 \mathrm{mg} / \mathrm{kg} \mathrm{BW}$

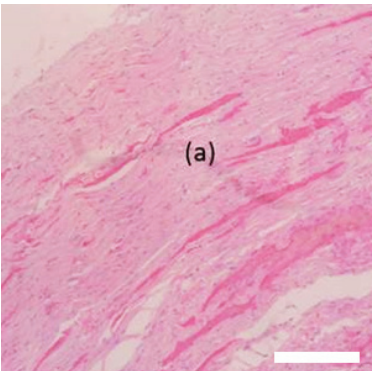

Dose $1000 \mathrm{mg} / \mathrm{kg} \mathrm{BW}$

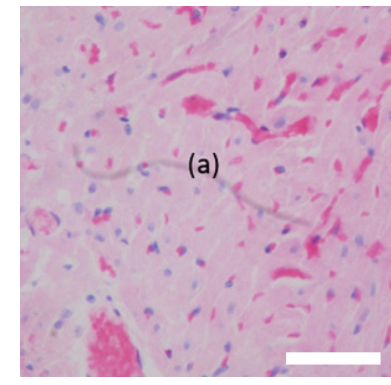

Dose 1000 mg/kg BW

Figure 4. Photomicrographs of heart histopathology of male and female controls and $S$. polyanthum extract-treated groups. (a): pericardium. No significant alteration was detected. White bar: $100 \mu \mathrm{m}$. 


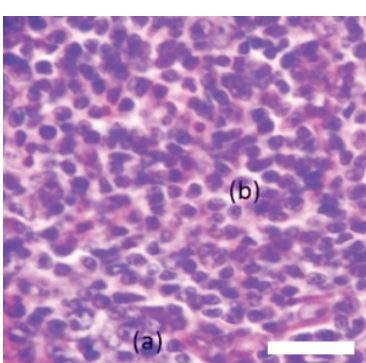

Control

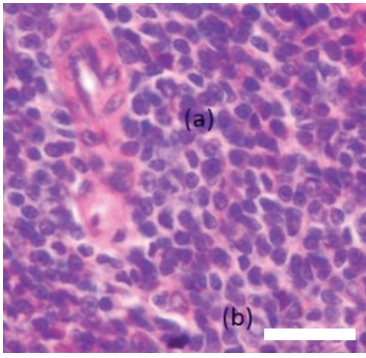

Control

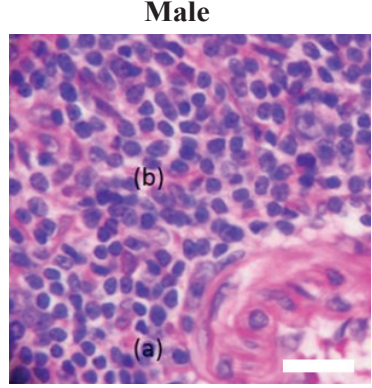

Dose $400 \mathrm{mg} / \mathrm{kg} \mathrm{BW}$

Female

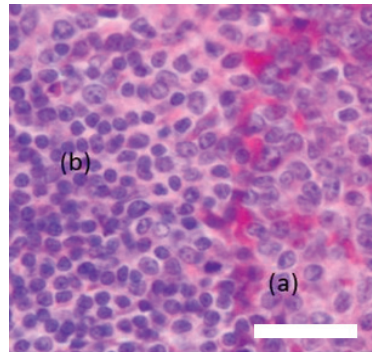

Dose $400 \mathrm{mg} / \mathrm{kg} \mathrm{BW}$

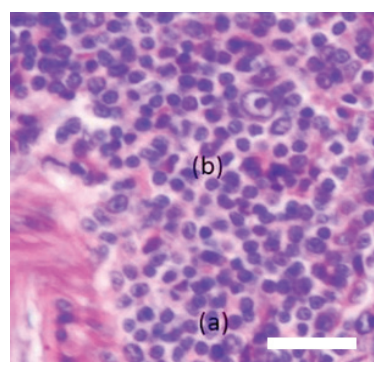

Dose $1000 \mathrm{mg} / \mathrm{kg} \mathrm{BW}$

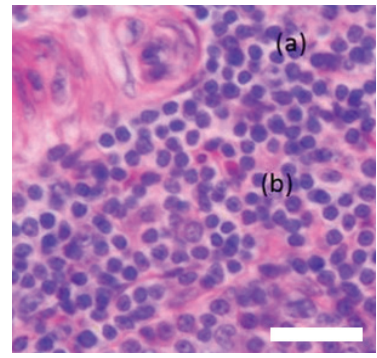

Dose $1000 \mathrm{mg} / \mathrm{kg} \mathrm{BW}$

Figure 5. Photomicrographs of spleen histopathology of male and female controls and $S$. polyanthum extract-treated groups. (a): pericardium. No significant alteration was detected. White bar: $100 \mu \mathrm{m}$.

\section{Conclusion}

Our study revealed that $S$. polyanthum extracts does not show toxicity on the body weight, hematology, creatinine and SGPT, but fatty liver and necrosis are observed in female rats. This result can be beneficial for plant-based drug discovery, particularly this study provides information about the safety of S. polyanthum to be further developed as candidate of phytopharmaceutics.

\section{References}

1. Dalimartha S. Atlas Tumbuhan Obat Indonesia. 1st ed. Jakarta: Trubus Agriwidya Indonesia; 1999.

2. Winarto WP. Memanfaatkan Bumbu Dapur untuk Mengatasi Aneka Penyakit. Jakarta: Agromedia Pustaka; 2004.

3. Peris I, Blázquez MA. Comparative GC-MS analysis of bay leaf (Laurus nobilis L.) essential oils in commercial samples. Int J Food Prop. 2015; 18: 757-62.

4. Sabir A. Pemanfaatan flavonoid di bidang kedokteran gigi. Dental Journal. 2003; Special Ed III: 81-7.

5. Nuratmi B, Winarno MW, Sundari S. Khasiat daun salam (Eugenia polyantha Wight) sebagai antidiare pada tikus putih. Media Litbangkes. 1998; Special Ed VIII: 14-7.

6. Martina LTUP. Pengaruh Pemberian Ekstrak Daun Salam (Eugenia polyantha) Terhadap Kadar LDL Kolesterol Serum Tikus Jantan Galur Wistar hiperlipidemia [Unpublished paper]. Semarang: Faculty of Medicine, Universitas Diponegoro; 2008.

7. Sumono A, Wulan A. Kemampuan air rebusan daun salam (Eugenia polyantha W) dalam menurunkan jumlah koloni bakteri
Spectroccocus sp. Majalah Farmasi Indonesia. 2009; 20: 112-7.

8. Kusuma IW, Kuspradini H, Arung ET, Aryani F, Min YH, Kim JS, Kim YU. Biological activity and phytochemical analysis of three Indonesian medicinal plants, Murraya koenigii, Syzygium polyanthum and Zingiber purpurea. J Acupunct Meridian Stud. 2011; 4: 75-9.

9. Lelono RA, Tachibana S. Bioassay-guided isolation and identification of antioxidative compounds from the bark of Eugenia polyantha. Pak J Biol Sci. 2013; 16: 812-8.

10. Widyawati T, Yusoff NA, Asmawi MD, Ahmad M. Antihyperglycemic effect of methanol extract of Syzygium polyanthum (Wight.) leaf in streptozotocin-induced diabetic rats. Nutrients. 2015; 7: 7764-80.

11. Darussalam M, Rukmi DK. Peran air rebusan daun salam (Syzigium polyanthum) dalam menurunkan kadar asam urat. Media Ilmu Kesehatan. 2016; 5: 83-91.

12. Hidayati MD, Ersam T, Shimizu K, Fatmawati S. Antioxidant activity of Syzygium polyanthum extracts. Indones J Chem. 2017; 17: 4953.

13. Fansworth NR. Biology and phytochemical screening of plants. J Pharm Sci. 1966; 55: 263-4.

14. Parasuraman S. Toxicology Testing. J Pharmacol Pharmacother. 2011; 2: 74-9.

15. Barduagni P, Ahmed AS, Curtale F, Rafaat M, Soliman L. Performance of Sahli and colour scale methods in diagnosing anaemia among school children in low prevalence areas. Trop Med Int Health. 2003; 8: 615-8.

16. Hor SY, Ahmad M, Farsi E, Lim CP, Asmawi Z, Yam MF. Acute and subchronic oral toxicity of Coriolus versicolor standardized water extract in Sprague-Dawley rats. J Ethnopharmacol. 2011; 137: 1067-76

17. Clausi AS. Subchronic toxicity studies. Food Cosmet Toxicol. 1978; 16: 83-92.

18. Hunter P. A toxic brew we cannot live without. Micronutrients give insights into the interplay between geochemistry and evolutionary biology. EMBO Rep. 2008; 9: 15-8. 